\title{
Influence of Motorization and Supermarket-Proliferation on the Prevalence of Type 2 Diabetes in the Inhabitants of a Small Town on Okinawa, Japan
}

\author{
Nobuyuki Takasu, Hiroyuki Yogi, Masaki Takara, Moritake Higa, Tsuyoshi Kouki, \\ Yuzuru Ohshiro, Goro Mimura and Ichiro Komiya
}

\begin{abstract}
Background Motorization and supermarket-proliferation affect lifestyles. About 15 years ago, Okinawans went to several shops on foot, but now they go to supermarkets by car. The influences of these changes on the prevalence of diabetes are uncertain.

Objective and Measurements The influence of motorization and supermarket-proliferation on the prevalence of diabetes was studied in the inhabitants of a town on Okinawa, Japan. Measurements were composed of anthropometry and blood chemistry. Participants were asked where they buy food and daily necessities (several shops or a supermarket) and how they get there (by car or on foot).

Design Serial cross-sectional.

Participants Inhabitants of the island of Okinawa were studied.

Results In 1991, 24\% went to several shops and $20 \%$ to a supermarket. However, in 2004, only $3.1 \%$ went to several shops and $83 \%$ to a supermarket. In 1991, 55\% went to shopping places on foot and $38 \%$ by car. However, in 2004 , only $14 \%$ went on foot and $76 \%$ by car. The prevalence of diabetes in Okinawa increased from $4.7 \%$ in 1991 to $8.4 \%$ in 2004 . The prevalence of diabetes correlated positively with the percent of inhabitants going to supermarkets, and those going there by car. In 1991, the prevalence of type 2 diabetes was $4.7 \%$ in men and $4.6 \%$ in women; no difference was noted between men and women. In 2004, the prevalence of type 2 diabetes increased to $9.2 \%$ in men and to $7.5 \%$ in women. The increase in the prevalence of type 2 diabetes from 1991 to 2004 was higher in men than in women.

Conclusions About 15 years ago, Okinawans went to shops on foot, but now they go to supermarkets by car. The prevalence of diabetes is increasing. Motorization and supermarket-proliferation are associated with the increases of the prevalence of diabetes. The increase in diabetes prevalence was higher in men than in women.
\end{abstract}

Key words: lifestyle, type 2 diabetes, diet, epidemiology, motorization, supermarkets, Okinawa, obesity

(DOI: 10.2169/internalmedicine.46.0387)

\section{Introduction}

Motorization and supermarket-proliferation affect lifestyles. About 15 to 30 years ago, Okinawans went to several shops (vegetable, fruit, fish, meat, and grocery shops) on foot, but now they go to supermarkets by car. This reflects a lifestyle change in Okinawans. Shopping is one of the basic behaviors of everyday life, and is part of our lifestyle. The questions are where to go for shopping and how to get there. Going to several shops on foot burns calories, but going to a supermarket by car does not.

Okinawans used to hold the unique distinction of having the highest longevity among the Japanese, and, indeed, in the world. The reasons for this longevity are considered to be a healthy diet, mild climate, and a less stressful society (1). Lifestyles have been changing on Okinawa. The proliferation of supermarkets has westernized dietary habits. 
Table 1. Characteristics of the Subjects (A) and Type 2 Diabetic Patients (B)

A. Subjects

\begin{tabular}{|c|c|c|c|c|c|c|c|}
\hline & 1991 & 1995 & 1999 & 2000 & 2001 & 2003 & 2004 \\
\hline Subjects $n$ & 1455 & 1499 & 1504 & 1522 & 1671 & 1502 & 1682 \\
\hline men & 701 & 750 & 750 & 760 & 835 & 750 & 844 \\
\hline women & 754 & 749 & 754 & 762 & 836 & 752 & 838 \\
\hline \multicolumn{8}{|l|}{ Age (years) } \\
\hline men & $56 \pm 9$ & $55 \pm 11$ & $58 \pm 14$ & $56 \pm 11$ & $52 \pm 10$ & $57 \pm 12$ & $55 \pm 10$ \\
\hline women & $54 \pm 7$ & $53 \pm 10$ & $56 \pm 10$ & $54 \pm 9$ & $54 \pm 11$ & $55 \pm 11$ & $57 \pm 13$ \\
\hline \multicolumn{8}{|l|}{ BMI $\left(\mathrm{kg} / \mathrm{m}^{2}\right)$} \\
\hline men & $21.4 \pm 2.2$ & $22.5 \pm 3.2$ & $23.6 \pm 3.2$ & $24.0 \pm 4.2$ & $24.2 \pm 3.2$ & $24.8 \pm 2.5$ & $24.9 \pm 3.3$ \\
\hline women & $21.9 \pm 2.3$ & $22.0 \pm 3.2$ & $22.7 \pm 2.1$ & $23.0 \pm 2.1$ & $24.0 \pm 3.1$ & $24.4 \pm 3.1$ & $24.6 \pm 3.2$ \\
\hline \multicolumn{8}{|l|}{ HbAlc (\%) } \\
\hline men & $4.8 \pm 0.3$ & $4.8 \pm 0.4$ & $4.8 \pm 0.4$ & $4.8 \pm 0.3$ & $4.9 \pm 0.3$ & $5.0 \pm 0.4$ & $5.1 \pm 0.4$ \\
\hline women & $4.8 \pm 0.3$ & $4.8 \pm 0.4$ & $4.8 \pm 0.4$ & $4.8 \pm 0.4$ & $4.9 \pm 0.4$ & $4.9 \pm 0.3$ & $5.0 \pm 0.5$ \\
\hline
\end{tabular}

Subjects, aged 40 or more and less than 70 years, were studied at time of their annual health checkup. No significant differences were noted in age, BMI, and HbA1c (means \pm SE) among 1991-, 1995-, 1999-, 2000-, 2001-, 2003-, and 2004-groups (Student's t-test).

B. Type 2 diabetic patients

\begin{tabular}{|c|c|c|c|c|c|c|c|}
\hline & 1991 & 1995 & 1999 & 2000 & 2001 & 2003 & 2004 \\
\hline Diabetic*n (\%) & $68(4.7)$ & $75(5.0)$ & $78(5.2)$ & $82(5.4)$ & $109(6.5)$ & $110(7.3)$ & $141(8.4)$ \\
\hline men & $33(4.7)$ & $39(5.2)$ & $40(5.3)$ & $44(5.8)$ & $60(7.2)$ & $59(7.9)$ & $78(9.2)$ \\
\hline women & $35(4.6)$ & $36(4.8)$ & $38(5.0)$ & $38(5.0)$ & $49(5.9)$ & $51(6.8)$ & $63(7.5)$ \\
\hline \multicolumn{8}{|l|}{ Age (years) } \\
\hline men & $57 \pm 10$ & $56 \pm 9$ & $57 \pm 15$ & $55 \pm 10$ & $53 \pm 12$ & $58 \pm 10$ & $56 \pm 12$ \\
\hline women & $55 \pm 8$ & $55 \pm 12$ & $57 \pm 12$ & $55 \pm 11$ & $54 \pm 12$ & $56 \pm 12$ & $57 \pm 15$ \\
\hline \multicolumn{8}{|l|}{$\operatorname{BMI}\left(\mathrm{kg} / \mathrm{m}^{2}\right)$} \\
\hline men & $22.4 \pm 3.2$ & $23.5 \pm 3.2$ & $24.4 \pm 3.6$ & $24.7 \pm 4.2$ & $24.9 \pm 3.2$ & $25.0 \pm 2.5$ & $25.4 \pm 3.3$ \\
\hline women & $22.3 \pm 2.3$ & $22.5 \pm 3.4$ & $23.2 \pm 3.1$ & $23.7 \pm 2.8$ & $24.2 \pm 3.1$ & $24.8 \pm 2.8$ & $25.1 \pm 2.8$ \\
\hline \multicolumn{8}{|l|}{ HbAlc (\%) } \\
\hline men & $6.4 \pm 1.1$ & $6.3 \pm 1.5$ & $6.4 \pm 1.8$ & $6.5 \pm 1.4$ & $6.5 \pm 1.7$ & $6.5 \pm 1.8$ & $6.6 \pm 1.7$ \\
\hline women & $6.3 \pm 0.9$ & $6.4 \pm 1.2$ & $6.4 \pm 1.7$ & $6.5 \pm 1.2$ & $6.5 \pm 1.5$ & $6.6 \pm 1.7$ & $6.5 \pm 1.4$ \\
\hline
\end{tabular}

Diabetic* n (\%): number of type 2 diabetic patients (\%: prevalence of diabetes). No significant differences were noted in age, BMI, and HbAlc (means \pm SE) among 1991-, 1995-, 1999-, 2000-, 2001-, 2003-, and 2004-groups (Student's t-test).

Western dietary habits and motorization have developed rapidly on Okinawa, which was under the jurisdiction of the $\mathrm{U}$. S. until 1972 following the Second World War. The penetration of Western habits began to negatively influence the traditional diet and lifestyles, as in Pima Indians (2). We undertook this study in an attempt to reveal the influence of motorization and supermarket-proliferation on the prevalence of type 2 diabetes in the inhabitants of a small town on Okinawa.

\section{Subjects and Methods}

\section{Design, setting, and participants}

We studied the inhabitants of a small town on Okinawa (Table 1); about 1500 people, aged 40 or older and less than 70 years, were studied at time of their annual health checkup in the period of March to April. The population of the town increased from 30,000 in 1991 to 36,000 in 2004. We undertook a series of cross-sectional studies.

We asked the subjects where they buy food and daily ne- 
cessities (several shops or a supermarket) and how they get there (by car or on foot). Written informed consent was obtained.

\section{Examinations and laboratory measurements}

Examinations were composed of anthropometry and blood chemistry (HbA1c, plasma glucose, total cholesterol, triglycerides, HDL-cholesterol, and complete blood cell counts). Total cholesterol, triglycerides, HDL-cholesterol, and complete blood cell counts were found to have no relation to this study. Blood samples were taken after an 8-h fast. HbA1c measurement was carried out by high-performance liquid chromatography (HPLC) (3). Body mass index (BMI) is defined as the individual's body weight $(\mathrm{kg})$ divided by the square of their height $(\mathrm{m})\left(\mathrm{kg} / \mathrm{m}^{2}\right)$.

\section{Definition}

Diabetes was defined by the following (3): 1) fasting plasma glucose $(\mathrm{FPG}) \geq 7.0 \mathrm{mmol} / \mathrm{l}, 2)$ casual plasma glucose $(\mathrm{CPG}) \geq 11.1 \mathrm{mmol} / \mathrm{l}, 3) \mathrm{HbA} 1 \mathrm{c} \geq 6.1 \%$, and 4) selfreported history of diabetes. The patients with type 1 diabetes were excluded from the study.

\section{Statistical analysis}

Chi-square was used to test the significance of differences between 1991- and 1995-, 1999-, 2000-, 2001-, 2003-, 2004-groups. (Fig. 1, 3) Pearson's product-moment correlation coefficient (r) was used to study the relationship between the prevalence of diabetes and percent $(\%)$ of the inhabitants, going to supermarkets or several shops, and between the prevalence of diabetes and percent $(\%)$ of those, going there by car or on foot (Fig. 2). When p values were less than 0.05 , the association was considered to be significant. Differences of means \pm SE [(HbA1c, plasma glucose, total cholesterol, triglycerides, HDL-cholesterol, complete blood cell counts and $\left.(\mathrm{BMI})\left(\mathrm{kg} / \mathrm{m}^{2}\right)\right]$ were assessed with Student's t-test.

\section{Results}

\section{A. Shopping places to buy food and daily necessi- ties and how to get there}

\section{Shopping places; several shops or a supermarket}

In 1991,349 of 1455 inhabitants (24\%) went to several shops and 291 of 1455 inhabitants (20\%) went to a supermarket (Fig. 1A). However, in 2004, only 52 of 1682 inhabitants $(3.1 \%)$ went to several shops and 1396 of 1682 inhabitants $(83 \%)$ went to a supermarket. Those who went to several shops decreased from $24 \%$ in 1991 to $3.1 \%$ in 2004 . Those who went to a supermarket increased from $20 \%$ in 1991 to $83 \%$ in $2004 ; 83 \%$ of the inhabitants conducted their shopping at a supermarket in 2004. Considering those who went to supermarket (closed circles in Fig. 1A), significant differences were noted between 1991- and 1995-groups
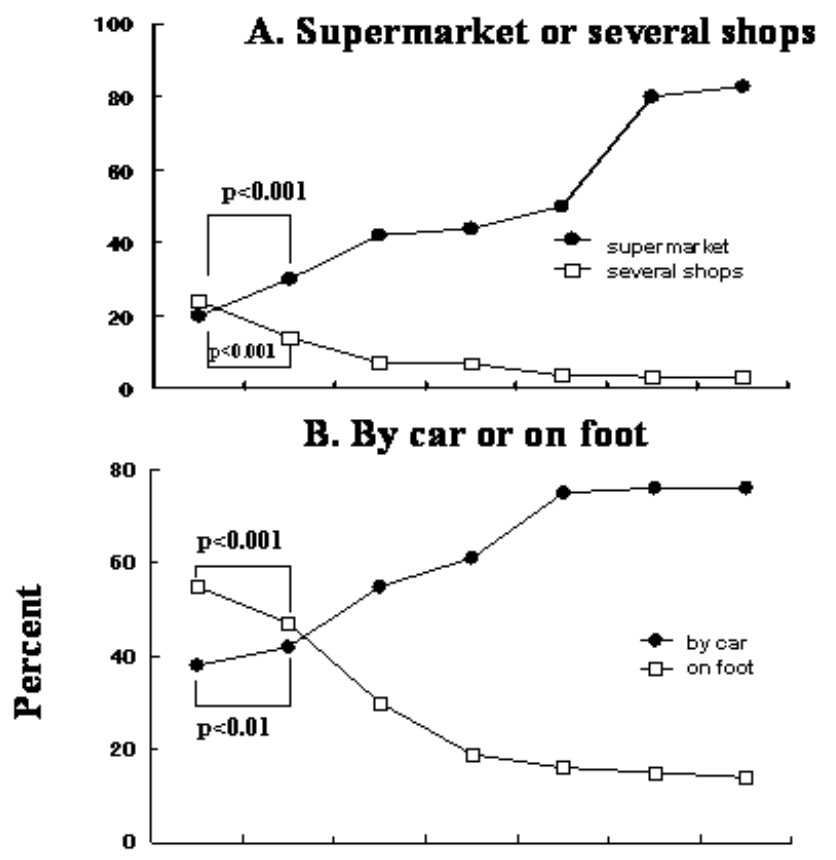

C. Prevalence of type 2 diabetes

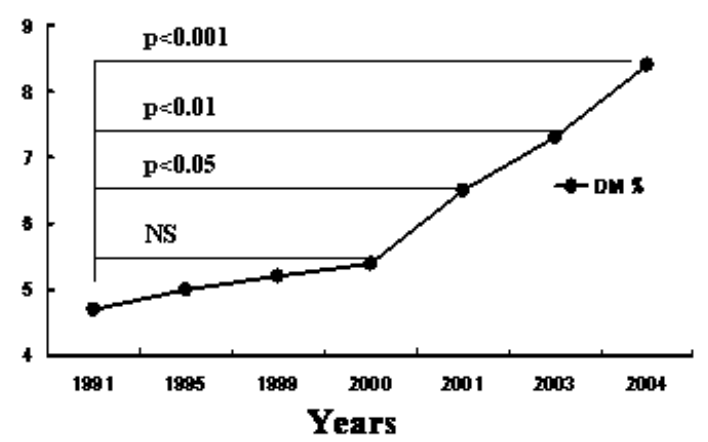

Figure 1. The ratio (\%) of inhabitants going to supermarket or several shops by car or on foot, and prevalence (\%) of type 2 diabetes each year. Shopping places (several shops or a supermarket) (A), means of transportation (by car or on foot) (B), and prevalence of type 2 diabetes (C). A: some (open squares) went to several shops, others (closed circles) went to a supermarket, and the remaining inhabitants went to both shops and supermarkets. Supermarket (closed circles); significant differences were noted between 1991- and 1995-, 1999-, 2000-, 2001-, 2003-, 2004-groups (Chi-square test). Several stores (open squares); significant differences were noted between 1991- and 1995-, 1999-, 2000-, 2001-, 2003-, 2004-groups. B: some (open squares) went to shopping places on foot, others (closed circles) by car, and the remaining inhabitants went both on foot and by car. By car (closed circles); significant differences were noted between 1991- and 1995-, 1999-, 2000-, 2001-, 2003-, 2004-groups. On foot (open squares); significant differences were noted between 1991- and 1995-, 1999-, 2000-, 2001-, 2003-, 2004-groups. C: Closed circles indicate prevalence of type 2 diabetes. The prevalence of type 2 diabetes in Okinawa increased from $4.7 \%$ in 1991 to $8.4 \%$ in 2004. No significant (NS) differences were noted between 1991- and 1995-, 1999-, 2000-groups but significant differences were noted between 1991- and 2001-, 2003-, 2004-groups. 


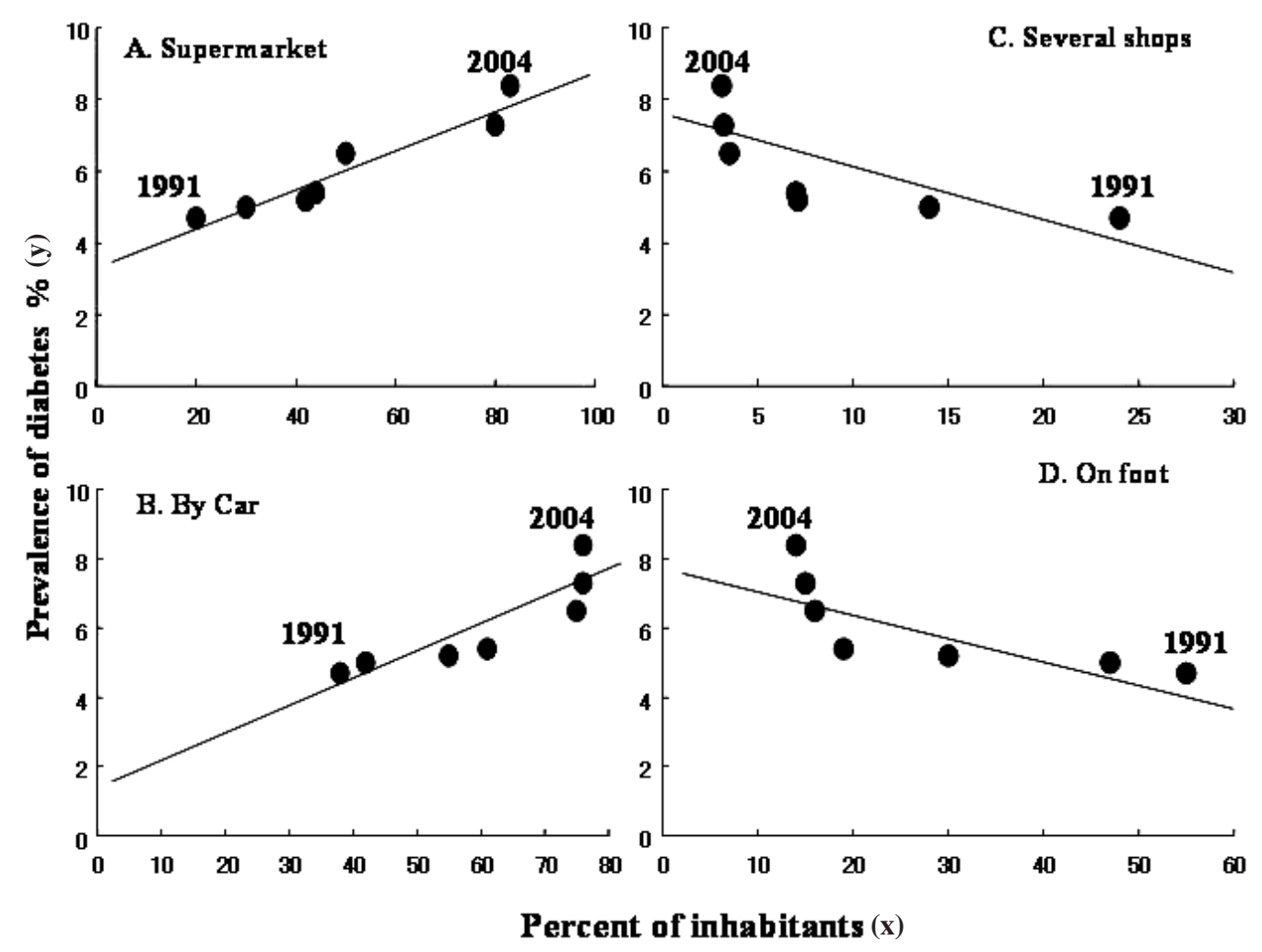

Figure 2. The relationships between the prevalence of diabetes (y) and the percent of inhabitants (x) going to supermarkets (A), going there by car (B), going to several shops (C) and going there on foot (D) in each year group. Scatterplots (closed circles) show the correlation between the prevalence of type 2 diabetes (y) and percent of the inhabitants (x), going to supermarkets (A), going there by car (B), going to several shops (C), and going there on foot (D). The prevalence (y) correlated positively with percent of the inhabitants $(x)$, going to supermarkets $(A)$, and going there by car (B), and negatively with percent of those, going to several shops (C), and going there on foot (D). A, B; $1991(1991) \rightarrow 1995 \rightarrow 1999 \rightarrow 2000 \rightarrow 2001 \rightarrow 2003 \rightarrow 2004$ (2004) (left to right), C, D; $2004(2004) \rightarrow 2003 \rightarrow 2001 \rightarrow 2000 \rightarrow 1999 \rightarrow 1995 \rightarrow 1991$ (1991) (left to right).

(Chi-square=39.447 $(\mathrm{p}<0.001))$, between 1991- and 1999groups $(\mathrm{p}<0.001)$, between 1991- and 2000-groups $(\mathrm{p}<$ 0.001 ), between 1991- and 2001-groups ( $\mathrm{p}<0.001)$, between 1991- and 2003-groups $(\mathrm{p}<0.001)$, and between 1991- and 2004-groups $(p<0.001)$. Considering those, who went to several stores (open squares in Fig. 1A), significant differences were noted between 1991- and 1995-groups (Chi-square= $47.902(\mathrm{p}<0.001))$, between 1991- and 1999-groups, between 1991- and 2000-groups ( $<<0.001)$, between 1991- and 2001-groups ( $\mathrm{p}<0.001)$, between 1991- and 2003-groups ( $\mathrm{p}<$ $0.001)$, and between 1991- and 2004-groups ( $<<0.001)$.

\section{Means of transportation; by car or on foot}

In 1991, 800 of 1455 inhabitants (55\%) went to shopping places on foot and 553 of 1455 inhabitants (38\%) went by car (Fig. 1B). However, in 2004, only 235 of 1682 inhabitants $(14 \%)$ went on foot and 1281 of 1682 inhabitants (76\%) went by car. Those who went on foot decreased from $55 \%$ in 1991 to $14 \%$ in 2004 . Those who went by car increased from $38 \%$ in 1991 to $76 \%$ in 2004 . In $2004,76 \%$ of the inhabitants went to shopping places by car. Considering those who went to shopping places by car (closed circles in
Fig. 1B), significant differences were noted between 1991and 1995-groups (Chi-square $=4.972 \quad(\mathrm{p}<0.01))$, between 1991- and 1999-groups (Chi-square=85.676 $(\mathrm{p}<0.001)$ ), between 1991- and 2000-groups $(\mathrm{p}<0.001)$, between 1991- and 2001-groups ( $\mathrm{p}<0.001$ ), between 1991- and 2003-groups ( $\mathrm{p}<$ 0.001 ), and between 1991- and 2004-groups $(\mathrm{p}<0.001)$. Considering those who went to shopping places on foot (open squares in Fig. 1B), significant differences were noted between 1991- and 1995-groups (Chi-square=18.679 ( $\mathrm{p}<$ $0.001)$ ), between 1991- and 1999-groups ( $\mathrm{p}<0.001)$, between 1991- and 2000-groups ( $<<0.001)$, between 1991- and 2001groups $(\mathrm{p}<0.001)$, between 1991- and 2003-groups $(\mathrm{p}<$ 0.001 ), and between 1991- and 2004-groups ( $<<0.001)$.

\section{B. Type 2 diabetes}

The prevalence of type 2 diabetes on Okinawa increased from $4.7 \%$ in 1991 to $8.4 \%$ in 2004 (Fig. 1C). No significant (NS) differences were noted between 1991- and 1995-, 1999-, 2000-groups but significant differences were noted between 1991- and 2001-groups (Chi-square=4.963 ( $\mathrm{p}<$ $0.05)$ ), between 1991- and 2003-groups (Chi-square $=9.174$ $(\mathrm{p}<0.01))$, and between 1991- and 2004-groups (Chi-square= 
$17.262(\mathrm{p}<0.001))$. Highly significant positive correlations were observed between the prevalence of type 2 diabetes (y) and percent $(\%)$ of the inhabitants $(\mathrm{x})$, going to supermarkets $(\mathrm{y}=0.06 \mathrm{x}+3.33, \mathrm{r}=0.96, \mathrm{p}<0.05)$ (Fig. 2A), and going there by car $(y=0.07 x+1.60, r=0.87, p<0.05) \quad$ (Fig. 2B). Negative correlations were observed between the prevalence of type 2 diabetes (y) and \% of those (x), going to several shops $(y=-0.13 x+7.22, r=-0.76, p<0.05)$ (Fig. 2C), and going there on foot $(y=-0.06 x+7.85, r=-0.77, p<0.05)$ (Fig. 2D).

The prevalence of type 2 diabetes on Okinawa increased from $4.7 \%$ in 1991 to $8.4 \%$ in 2004 (Fig. 1C, Table 1B). As shown in Fig. 3 and Table 1B, in 1991, the prevalence of type 2 diabetes was $4.7 \%$ in men and $4.6 \%$ in women; no difference of the prevalence was noted between men and women. In 2004, the prevalence of type 2 diabetes increased to $9.2 \%$ in men and to $7.5 \%$ in women. The increase in the prevalence of type 2 diabetes from 1991 to 2004 was higher in men than in women. In the prevalence of type 2 diabetes in men (closed squares in Fig. 3), significant differences were noted between 1991- and 2001-groups (Chi-square= $4.25(\mathrm{p}<0.05)$ ), between 1991- and 2003-groups (Chisquare $=6.04(\mathrm{p}<0.05))$, and between 1991- and 2004-groups $($ Chi-square $=11.855(\mathrm{p}<0.05))$. In the prevalence of type 2 diabetes in women (open squares in Fig. 3), significant differences were noted between 1991- and 2004-groups [Chisquare $=5.668(\mathrm{p}<0.05)]$. Mean values of BMI increased from 21.4 to 24.9 in men and from 21.9 to 24.6 in women in the subjects (Table 1A) and mean values of BMI increased from 22.4 to 25.4 in men and from 22.3 to 25.1 in women in diabetic patients (Table 1B), although these increases were not statistically significant.

\section{Discussion}

Motorization and supermarket-proliferation have changed lifestyles. About 15 to 30 years ago, Okinawans usually went to several shops on foot, but now they go to supermarkets by car. The prevalence of type 2 diabetes is increasing. The increase in diabetes prevalence was higher in men than in women. Motorization and supermarket-proliferation seem to be associated with the increases in the prevalence of type 2 diabetes. Type 2 diabetes-prevalence is increasing.

Motorization and supermarket-proliferation have developed rapidly on Okinawa. Motorization has changed the habits of Okinawans. They have stopped walking and now go to supermarkets by car. The supermarket-proliferation westernized dietary habits. The penetration of Western habits has brought about the supermarket-proliferation in turn. The inhabitants now go to supermarkets by car rather than go to several shops on foot. Motorization and Western dietary habits have developed rapidly on Okinawa. The penetration of Western habits began to negatively influence traditional diet and lifestyles. Motorization and supermarket-proliferation seem to be associated with the increase in type 2 diabetes. The increase in diabetes prevalence was higher in men than in women (Fig. 3). In 2004, BMI-values were also

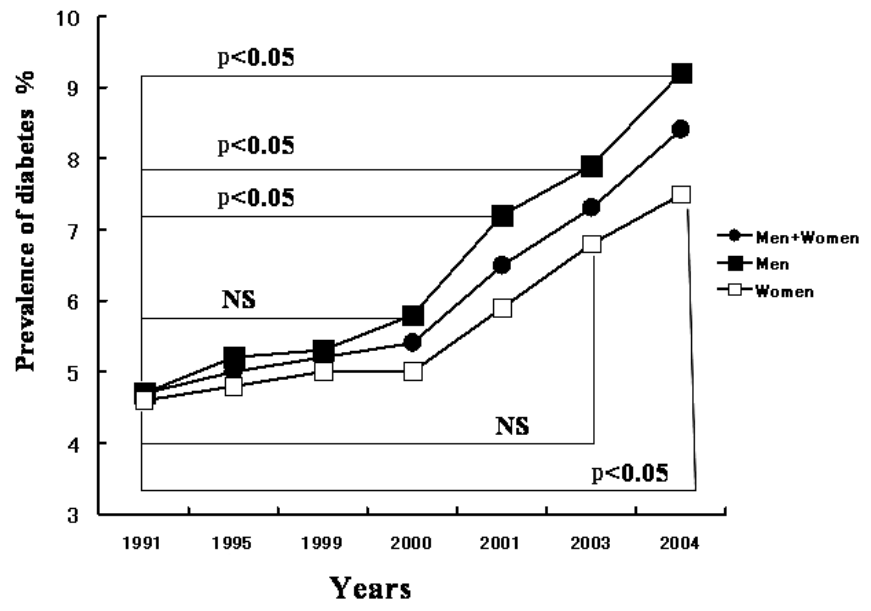

Figure 3. Prevalence of type 2 diabetes in men (closed squares) and women (open squares) in each year. In 1991, the prevalence of type 2 diabetes was $4.7 \%$ in men and $4.6 \%$ in women. In 2004, the prevalence of type 2 diabetes increased to $9.2 \%$ in men and to $7.5 \%$ in women. The increases in the prevalence of type 2 diabetes from 1991 to 2004 were higher in men than in women. In men (closed squares), significant differences were noted between 1991- and 2001-groups, between 1991- and 2003-groups, and between 1991- and 2004groups (Chi-square test). In women (open squares), significant differences were noted between 1991- and 2004-groups. Closed circles indicate the prevalence of type 2 diabetes in men+women.

increased. From 1991 to 2004, the mean values of BMI increased from 21.4 to $24.9 \mathrm{~kg} / \mathrm{m}^{2}$ in men and from 21.9 to $24.6 \mathrm{~kg} / \mathrm{m}^{2}$ in women in the subjects and mean values of BMI increased from 22.4 to $25.4 \mathrm{~kg} / \mathrm{m}^{2}$ in men and from 22.3 to $25.1 \mathrm{~kg} / \mathrm{m}^{2}$ in women in diabetic patients. The diabetes prevalence was higher in men than in women. In 2004, $52 \%$ of the men (age $\geq 40$ years old) had BMI $\geq 25 \mathrm{~kg} / \mathrm{m}^{2}$ and $37 \%$ of the women (age $\geq 40$ years old) had BMI $\geq 25$ $\mathrm{kg} / \mathrm{m}^{2}$. In $1991,40 \%$ of the men (age $\geq 40$ years old) had BMI $\geq 25 \mathrm{~kg} / \mathrm{m}^{2}$ and $35 \%$ of the women (age $\geq 40$ years old) had BMI $\geq 25 \mathrm{~kg} / \mathrm{m}^{2}$. This higher prevalence of obesity (BMI $\geq 25 \mathrm{~kg} / \mathrm{m}^{2}$ ) in men than in women might explain the higher prevalence of diabetes in men than in women.

Following the Second World War, Western habits began to negatively influence the traditional Okinawan diet and lifestyle to such an extent that by 1975 cholesterol intake on Okinawa was double that in other parts of Japan. Okinawan diet shifted from a classical Okinawan diet, characterized by vegetables, sweet potatoes, and seafood (1) to a western diet, dominated by meats and fast foods, such as hamburgers. Schulz et al (2) studied the effects of traditional and western environments on the prevalence of type 2 diabetes in Pima Indians in Mexico and the U.S. and they concluded that the changes in lifestyle associated with Westernization played a major role in the global epidemic of type 2 diabetes. Schulze et al (4) reported the importance of anthropometric, dietary, and lifestyle factors to predict the development of type 2 diabetes. 
Japanese longevity ranks first in the world (1) with Okinawan women at the top of this ranking. Japan has the highest percentage of centenarians in the world. There are 32,295 centenarians in Japan at September 15, 2007; 85\% of them are women. There are 792 centenarians in Okinawa. Okinawa has the largest number of centenarians/population; $58 / 100,000$ in Okinawa and 24/100,000 in Japan at September 15,2007 . The reasons for this longevity are considered to be a healthy diet, mild climate, and a less stressful society (1). Okinawans used to hold the unique distinction of having the highest longevity among the 47 prefectures of Japan, and, indeed, the world. The negative influence of Western habits on the traditional diet and lifestyles means that the prospects for continued longevity among the Okinawans do not look bright. The recent trends in lipid consumption and disease patterns on Okinawa are thus a reflection of the most rapid westernization observed among Japanese prefectures. Although the westernization of foods in Okinawa has preceded the rest of Japan, other regions will soon follow. This may be the most predictive factor for a shortened life span among the Japanese population. The retrospective analysis of the Okinawan diet simply reveals it to be a close reflection of the American diet, which underwent the same changes nearly 60 years earlier. The prevalence of type 2 diabetes, obesity, and hyperlipidemia are increasing in the inhabitants of a small town on Okinawa. This local study suggests the trend that will occur among the larger Japanese population in the future.

This study has shown the increase in the prevalence of type 2 diabetes from 1991 to 2004 in the inhabitants of a small town on Okinawa. The inhabitants have similar genetic background but they live in differing environmental circumstances. The low prevalence of type 2 diabetes and obesity in 1991 in a more traditional rural environment contrasts sharply with that in 2004. In 2004, they are living in a Westernized environment. The difference in diabetes prevalence between in 1991 and in 2004 is mirrored by the differences in physical activity and obesity. Type 2 diabetes is not inevitable and is preventable in environments that promote low levels of obesity and high levels of physical activity.

The results are from a series of cross-sectional studies. Our study has some limitations. This is a study based on randomly selected inhabitants from the same population. An apparent weakness, compared to a prospective cohort design, is that some of what is measured as change over time might be an effect studying different samples, although some individuals had been followed serially. The size of the samples chosen should limit risk. However, $4.6 \%$ of the population had been studied from 1991 to 2004. This cross-sectional study demonstrated that motorization and supermarketproliferation increased the prevalence of type 2 diabetes in the inhabitants of a small town on Okinawa.

\section{Conclusions}

About 15 years ago, Okinawans went to shops on foot, but now they go to supermarkets by car. The prevalence of diabetes is increasing. Motorization and supermarket-proliferation seem to be associated with the increases of the prevalence of diabetes. The increase in diabetes prevalence was found to be higher in men than in women.

Abbreviations: BMI: body mass index, HbA1c: glycosylated hemoglobin A1c, FPG: fasting plasma glucose

\section{References}

1. Willcox BJ, Willcox DC, Suzuki M. The Okinawa Program: How the World's Longest-Lived People Achieve Everlasting HealthAnd How You Can Too. Three Rivers Press, New York, New York, 2001: 1-484.

2. Schulz LO, Bennett PH, Ravussin E, et al. Effects of traditional and western environments on prevalence of type 2 diabetes in Pima Indians in Mexico and the U.S. Diabetes Care 29: 18661871, 2006

3. Takahashi Y, Noda M, Tsugane S, Kuzuya T, Ito C, Kadowaki T.
Prevalence of diabetes estimated by plasma glucose criteria combined with standardized measurement of HbAlc among health checkup participants on Miyako Island, Japan. Diabetes Care 23: 1092-1096, 2000.

4. Schulze MB, Hoffmann K, Boeing H, et al. An accurate risk score based on anthropometric, dietary, and lifestyle factors to predict the development of type 2 diabetes. Diabetes Care 30: 510-515, 2007.

(C) 2007 The Japanese Society of Internal Medicine http://www.naika.or.jp/imindex.html 